\title{
The diagnosis and treatment of donovanosis (granuloma inguinale)
}

\author{
J Richens
}

\begin{abstract}
Donovanosis is a predominantly tropical cause of genital ulcer occurring chiefly in small endemic foci in all continents except Europe. Diagnosis requires the careful collection, staining and examination of smears or biopsies of characteristic genital and, occasionally, extragenital lesions for demonstration of the pathognomonic Donovan bodies (Calymmatobacterium granulomatis) within histiocytes. Successful isolation of C. granulomatis has rarely proved feasible, the last report being in 1962. Donovanosis has a characteristic histopathological picture which occasionally simulates epithelioma. The antibiotics reported as showing good activity in donovanosis are those with good activity against gram negative bacilli and whose lipid solubility ensures good intracellular penetration. They include streptomycin, choramphenicol, erythromycin, lincomycin, cotrimoxazole and the tetracyclines. More recently, good results have been reported with norfloxacin and thiamphenicol. The treatment of donovanosis in pregnant women and patients with AIDS poses special problems. Complications of donovanosis such as elephantiasis, stricture and pelvic abscess may require surgery. Contacts should be traced for examination but only treated if lesions are found.
\end{abstract}

\section{Introduction}

The diagnosis and treatment of donovanosis was last reviewed in this journal 40 years ago by Greenblatt and Barfield ${ }^{1}$ who made many important contributions to the study of this neglected disease. Since that review, progress in our understanding of donovanosis has been painfully slow; no successful isolations of the causative organism, Calymmatobacterium granulomatis, have been reported in the past 30 years. Although the days when Greenblatt could estimate that there were 10000 cases in the

London School of Hygiene and Tropical Medicine, London, UK

J Richens
United States of America ${ }^{2}$ are long gone, the disease remains prevalent in many of its other endemic areas and currently appears to be making a resurgence in South Africa. ${ }^{34}$

\section{Distribution}

Donovanosis has an unusual geographical distribution, predominantly tropical, but concentrated in certain regions and, in others, apparently absent (fig 1). It is most well known in south-east India, where it was first described, ${ }^{5}$ in New Guinea, the Caribbean and neighbouring parts of South America, particularly the Guianas and Brazil. Additional foci are found in Zambia, South Africa, Vietnam, Japan and among Australian aboriginals. The current status of donovanosis in China, Malaysia, Zimbabwe and West Africa is not known to the author although it has been reported in all these places in the past. It has all but disappeared now from the southern states of the USA. Knowledge of the special distribution of donovanosis assists with its recognition in endemic areas and may alert clinicians to the possibility of donovanosis in unusual cases of genital ulcer in patients giving a history of travel to these areas.

\section{Clinical diagnosis}

While the clinical features of donovanosis lesions are sufficiently characteristic to suggest the correct diagnosis in most cases, the plethora of variants, ${ }^{6}$ atypical lesions $^{78}$ and presentations ${ }^{9-16}$ that have been described should serve as a reminder that the accurate clinical diagnosis of donovanosis, as with other forms of genital ulcer, is fraught with pitfalls, even in the most experienced hands. In typical cases the patient will give a history of sexual contact (not infrequently with a prostitute) 3 to 40 days $^{17}$ prior to the appearance of the initial lesion. This is generally a small papule which may be preceded and accompanied by pruritus. Ulceration soon follows. The predominant sites for primary lesions are the distal penis for men and introitus for women. Many other sites may be involved either as a primary event or by secondary spread. The most important are the groins, the anus (especially in homosexuals ${ }^{18}$ ), the cervix (see below, Intrapelvic donovanosis.) and various sites remote from the genitalia, the commonest of which are the neck and mouth. ${ }^{19}$ In its most characteristic form, donovanosis is an infection 


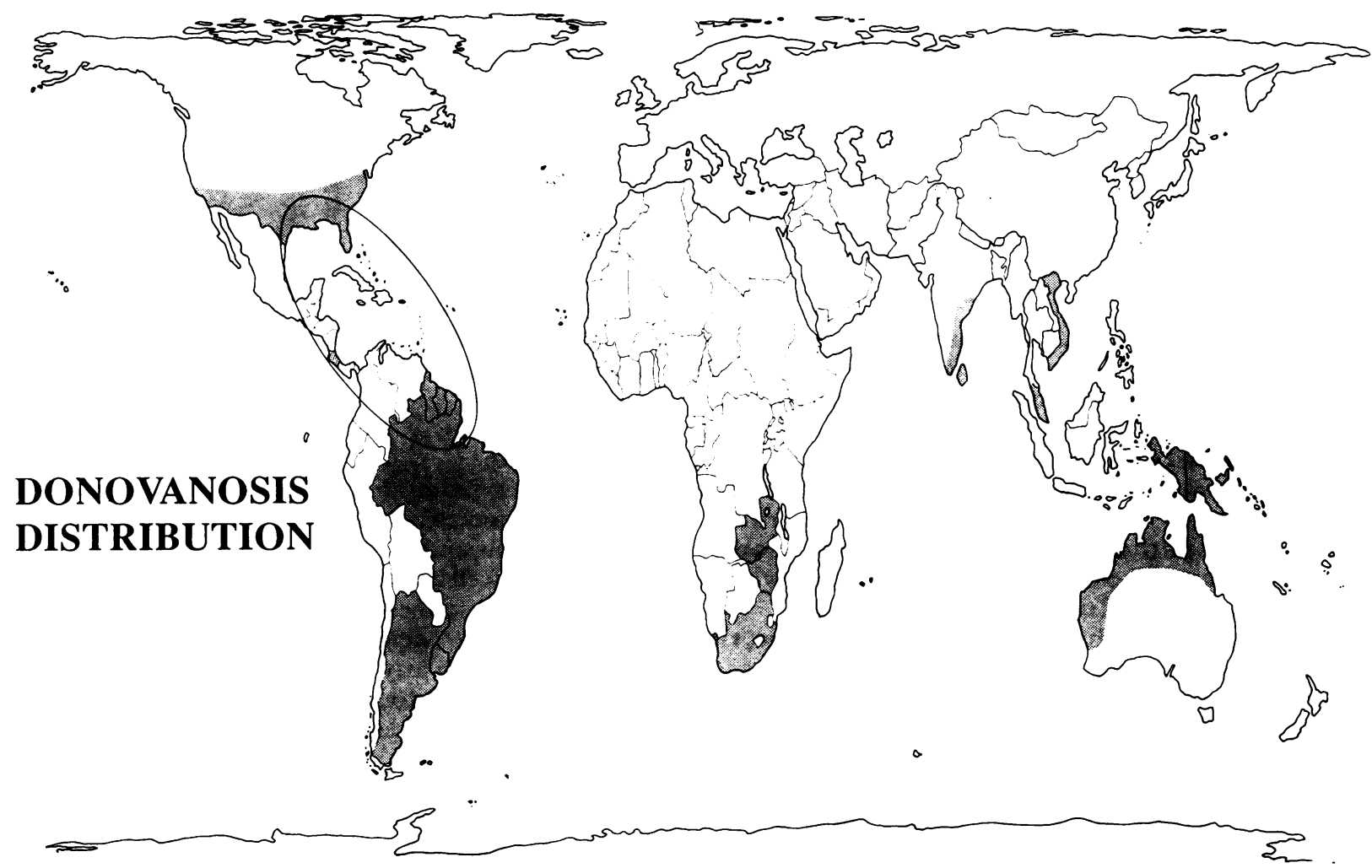

Fig 1 Principal areas from which donovanosis has been reported.

which produces slowly extending, relatively painfree, velvety genital ulcers with a bright red colour (traditionally likened to raw beef). The lesions bleed easily. Induration is very variable but rarely prominent in young lesions. Systemic symptoms are notably absent except for cases with very extensive or intra-pelvic spread, secondary infection or the very rare cases with haematogenously disseminated disease. ${ }^{20}$ Extension along skin folds and contact (kissing) lesions on apposed surfaces are characteristic. While inguinal ulceration is a common feature many observers have commented on the infrequent occurrence of lymph node enlargement in this disease. The explanation for these apparently contradictory observations appears to be that lymphatic spread to the inguinal glands occurs but enlargement or suppuration of these glands is infrequent. Instead, the infection tends to escape into the surrounding tissues, producing a periadenitis which may lead to the formation of an abscess (for which the term "pseudobubo", was coined by Greenblatt ${ }^{21}$ ) but more usually results in ulceration of the overlying skin. Lesions of donovanosis are frequently elevated above the level of the surrounding skin (fig 2), with a smooth rolled edge. A serpiginous outline is characteristic of larger lesions (fig 3). In some patients extensive scarring accompanies active disease. The rarity of these cicatricial lesions in Melanesians was noted in the classic original paper by Conyers and Daniels ${ }^{22}$ and can be confirmed by the present author.

\section{Differential diagnosis}

Donovanosis has to be distinguished from other infectious and non-infectious causes of genital ulcer, bubo and genital elephantiasis. In practice the lesions which are most likely to cause confusion are primary and secondary syphilis, ${ }^{23}{ }^{24}$ ulcerated genital warts, squamous carcinoma ${ }^{25}$ and chancroid. ${ }^{26}$ Early lesions can pose difficulty because the differentiating characteristics are less well developed. ${ }^{24}$ The problem of differentiating syphilis is compounded by the high proportion of donovanosis patients who acquire both infections together. For instance Vacca and MacMillan reported positive syphilis serology in $30 \%$ of a series of women with confirmed anogenital lesions due to donovanosis ${ }^{27}$ and Lal and Nicholas reported 


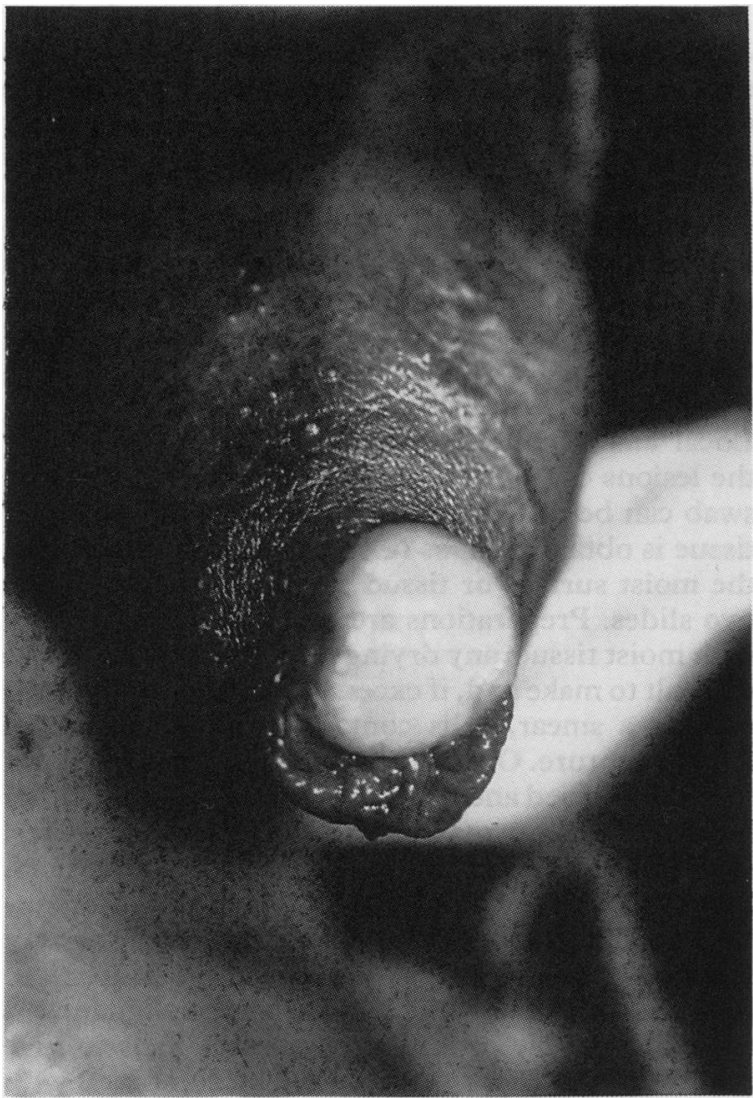

Fig 2 Early lesion of donovanosis in male.

concurrent syphilis in $45.5 \%$ of 165 cases of donovanosis. ${ }^{28}$ Further, non-pathogenic spirochaetes are found with such frequency in donovanosis lesions that they led early researchers to conclude that donovanosis was caused by these organisms. ${ }^{29}$ Recently attention has been drawn to a variant of chancroid with a strong resemblance to donovanosis $^{3031}$ and dubbed "pseudogranuloma inguinale" by some writers. ${ }^{32}$ All of these diseases have been reported to co-exist with donovanosis, in particular syphilis. However, the older literature is bedevilled by a lack of sufficiently specific diagnostic tests for lymphogranuloma venereum (LGV) and chancroid which make it impossible to be certain about the true aetiology of genital ulcers described in many papers. LGV is constantly confused with donovanosis in the literature because of the host of similar synonyms used for both, as well as similarities of clinical picture and geographical distribution. In particular, the confusing term "lymphogranuloma inguinale" has been employed by some authors to refer to donovanosis and by others to refer to LGV.$^{33}$ Clinically, LGV is best distinguished by the prominence of systemic symptoms in its early stages, and by its tendency to cause proctitis, lymphangitis and lymphadenitis with

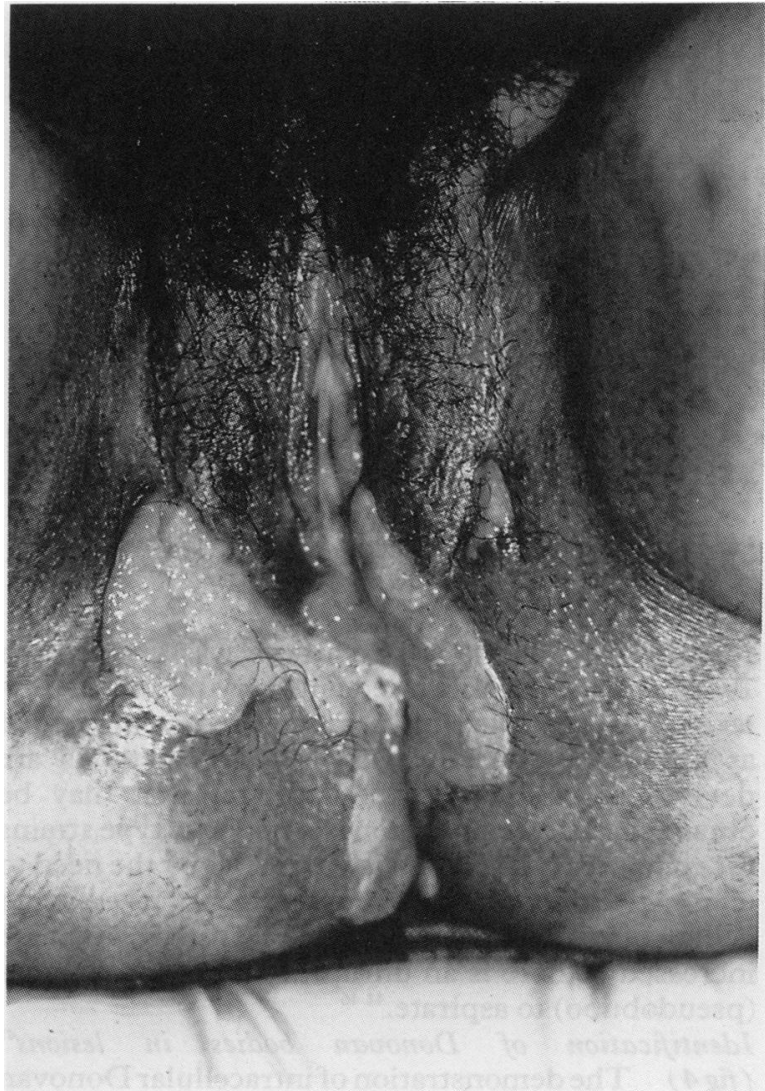

Fig 3 Advanced lesion of donovanosis in female.

discharging sinuses. Skin ulceration occurs but, apart from the primary lesion, which is generally small and often passed unnoticed, it is a late secondary feature, rather than the main pathological event, as in donovanosis. Labial fenestration and the combination of ulceration with elephantiasis termed esthiomène have been described as diagnostic of LGV. This is incorrect; all these findings occur in donovanosis patients also. ${ }^{34}$

\section{Confirming the diagnosis of donovanosis}

Isolation of Calymmatobacterium granulomatis This curious bacterium was named by Aragâo and Vianna in $1913^{35}$ but not convincingly isolated until 1942 when Kathleen Anderson obtained pure growth, in the yolk sac of fertile chick eggs, of a capsulated Gram negative bacillus, with a close morphological resemblance to the bacteria seen in smears of donovanosis lesions. ${ }^{36}{ }^{37}$ These isolates failed to grow on conventional solid media. Antigen preparations provoked strong complement fixation reactions when tested with large numbers of sera from verified cases of donovanosis. ${ }^{38}$ The bacteria were subsequently adapted to a number of liquid media. ${ }^{3940412}$ In all, some 14 isolates have been 


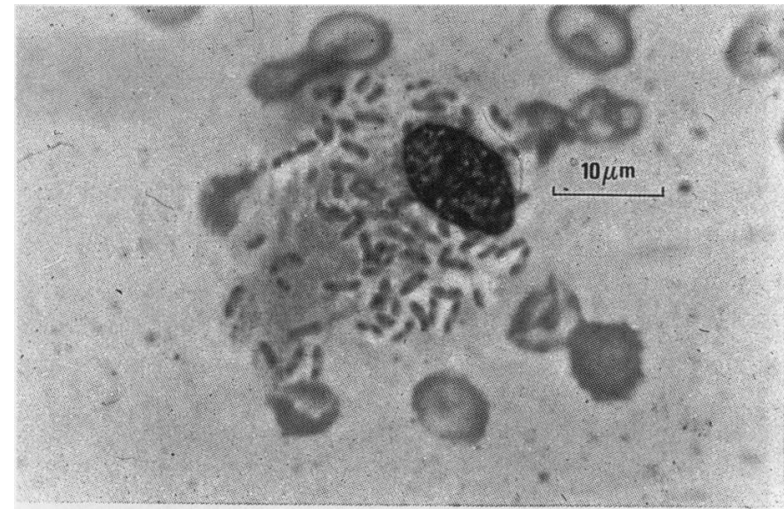

Fig 4 Donovan bodies in mononuclear cell (Giemsa, $\times 1000$ ).

reported. ${ }^{374143-48}$ The last of these was reported in $1962^{48}$ and the organism remains very poorly characterised. Isolation attempts cannot be recommended as a routine procedure until better methods are devised to characterise any isolates that may be obtained. Culture collections do not have type strains for comparison. Isolation is hampered by the need to eliminate the numerous contaminants present in genital ulcers. The chances of successful isolation are increased if there is an unruptured inguinal abscess (pseudobubo) to aspirate. ${ }^{4146}$

Identification of Donovan bodies in lesions ${ }^{49}$ (fig 4) The demonstration of intracellular Donovan bodies in material from lesions has remained the "gold standard" for the diagnosis of donovanosis ever since they were first described by Donovan in $1905 .^{50}$ The finding of Donovan bodies provides a simple, highly specific way of confirming the diagnosis. They can be demonstrated, in $60-80 \%$ of cases, ${ }^{51}$ in either direct smears, or biopsy specimens. Good technique in making and staining the smear, careful searching and familiarity with the appearance of Donovan bodies are all important. Morphological details of Donovan bodies are easier to recognise in well-made smears than in tissue sections, ${ }^{5253}$ but, in patients with negative smears, the demonstration of Donovan bodies may only be possible after a careful examination of sections. More rarely they have been identified in inguinal pseudobubo aspirates, ${ }^{49}$ cytology specimens, ${ }^{54556}$ and, in an isolated report of an atypical case, in peripheral blood monocytes. ${ }^{57}$ The characteristics of the Donovan body are sufficiently individual to distinguish it from other microorganisms that parasitise macrophages in the skin (tables 1 and 2).

The closest resemblance is seen with the Frisch bacilli (Klebsiella rhinoscleromatis) of rhinoscleroma which produce lesions with a close histological similarity to donovanosis. Electron microscopic appearances of $C$. granulomatis have been described but are not specific. ${ }^{395859606162}$
Techniques for the demonstration of Donovan bodies Smear and biopsy An active area of ulceration should be selected and cleansed with saline or a disinfectant. The leading edge of an ulcer is usually chosen, although material from the base of the ulcer may also be satisfactory. Cells may be obtained by a variety of means. Direct impressions on a glass slide are not usually adequate because surface debris and other bacteria are liable to obscure the picture. It is best to detach a small piece of tissue. The infected tissue is usually friable and easily detached with forceps, a curette, scalpel blade or punch biopsy. Local anaesthetic may be necessary. Alternatively the lesions can be scraped with a scalpel or a cotton swab can be rolled over the surface of the lesion. If tissue is obtained, dabs or smears can be made from the moist surface or tissue can be crushed between two slides. Preparations are best made immediately with moist tissue; any drying renders the smear more difficult to make and, if excessive drying occurs while making a smear, cells containing Donovan bodies tend to rupture. Once the smear has been made it can then be air dried and heat fixed before staining. Other forms of fixation may shrink the Donovan bodies. Repeated smears are recommended by some authors. Biopsy is recommended for lesions in which organisms are likely to be scarce, that is, very early or very sclerotic lesions and those with heavy superinfection. Biopsy is mandatory in cases where malignancy is thought possible or antibiotic therapy fails to give improvement. Biopsy can always be combined with smears from the cut surface of the specimen. A wide variety of stains will demonstrate Donovan bodies. For smears, Giemsa, Leishman or Wright's stain are all satisfactory. Giemsa staining takes considerably longer unless newer rapid Giemsa techniques are used. ${ }^{63}$ When Wright's stain is used, Dienst et al recommend extending the initial staining in undiluted solution to one and a half minutes. ${ }^{64}$ For fixed, embedded tissue the least satisfactory results have been obtained with haematoloxylin and eosin, though Pund favoured Delafield's haematoloxylin with a small amount of eosin. ${ }^{65}$ Most prefer Giemsa or silver stains. The use of semi-thin sections, although more expensive and time-consuming, demonstrates Donovan bodies with impressive clarity ${ }^{596}$ and can be recommended for difficult cases. Good results have been reported recently with a slow Giemsa $^{67}$ and with thionine azure II basic fuchsin. ${ }^{66}$

\section{Histological features of donovanosis ${ }^{6568-71}$}

(1) The large mononuclear cells containing Donovan bodies are described in table 1 . These cells are scattered diffusely through the dermis. D'Aunoy and Von Haam have drawn attention to the presence of histiocytes containing Donovan bodies deep within areas of fibrosis in some cases. ${ }^{72}$.

(2) The epidermis at the borders of ulcers commonly shows some degree of hyperplasia, ranging from 
Table 1 Characteristics of Donovan bodies

Morphology of Donovan bodies: pleomorphic 1-2 $\times 0.5-0.7 \mu \mathrm{m}$. A capsule is often visible but the extent to which this takes up stain varies considerably from case to case and according to the technique used. Bipolar densities giving closed safety-pin appearance are often observed. No spore. Non-motile.

Staining properties: Gram negative, well seen with Giemsa, Leishman, Wright's or silver stains; poorly visualised with haematoxylin and eosin; not acid-fast.

Host cell: large mononuclear cells $20-90 \mu \mathrm{m}$ in diameter scattered throughout the dense plasma cell infiltrate of the lesion. Nucleus often oval, eccentric and vesicular or pyknotic. Vacuolated cytoplasm containing clusters of Donovan bodies which are, occasionally, confined to the periphery of the phagosomes.

Other sites for Donovan bodies: occasional extracellular forms and organisms within polymorphonuclear neutrophils.

Table 2 Differential diagnosis of Donovan bodies

\begin{tabular}{|c|c|}
\hline Condition & Description of inclusions \\
\hline Rhinoscleroma & $\begin{array}{l}2-3 \mu \mathrm{m} \text { Frisch bacilli (Klebsiella rhinoscleromatis) in Mikulicz cells closely resemble } \\
\text { Donovan bodies. Mikulicz cells, slightly larger and more abundant than the large } \\
\text { histiocytes of donovanosis. In rhinoscleroma PAS +ve } 20-40 \mu \mathrm{m} \text { Russell bodies also } \\
\text { occur. }\end{array}$ \\
\hline Leishmaniasis & $\begin{array}{l}\text { Leishman-Donovan bodies (not to be confused with Donovan bodies }{ }^{\star} \text { ) are } 2-4 \mu \mathrm{m} \text { non- } \\
\text { encapsulated amastigotes of leishmania species showing a separate kinetoplast } \\
\text { (paranucleus) within } 20-30 \mu \mathrm{m} \text { macrophages. Nucleus and kinetoplast stain bright red } \\
\text { with Giemsa. }\end{array}$ \\
\hline Lymphogranuloma venereum & $\begin{array}{l}\text { Chlamydial inclusion bodies identifiable by iodine, Giemsa or fluorescent antibody } \\
\text { staining. }\end{array}$ \\
\hline Histoplasmosis & $\begin{array}{l}\text { Round or oval } 2-4 \mu \mathrm{m} \text { inclusions with clear halo, not in vacuoles, occurring in epithelioid } \\
\text { granulomas with foci of necrosis. Inclusions deeply basophilic with Gram or Giemsa and } \\
\text { also take up PAS and methenamine silver. }\end{array}$ \\
\hline Chronic lymphocytic cervicitis & Tingible body macrophages, heavy lymphocytic infiltrate. \\
\hline Malakoplakia & $\begin{array}{l}\text { Michaelis-Gutmann bodies, round, often lamellated, } 5-15 \mu \mathrm{m} \text { in diameter, within von } \\
\text { Hansemann cells (macrophages with eosinophilic granules). Inclusions are PAS positive, } \\
\text { diastase resistant and stain positively with von Kossa and Perls' stains. }\end{array}$ \\
\hline
\end{tabular}

*The same Donovan discovered inclusion bodies in both diseases within a two year period. He initially wrote of what are now called Leishman-Donovan bodies of visceral leishmaniasis as "Donovan bodies", while further confusion was caused by later writers referring to Leishman-Donovan bodies in donovanosis instead of Donovan bodies.

a mild acanthosis to pseudoepitheliomatous hyperplasia with pearl formation sufficient to cause confusion with true malignancy on occasion. ${ }^{7374}$ The dangers of this are highlighted by Rajam and Rangiah who state, "Marked and irregular epithelial hyperplasia, simulating neoplasia histologically, in the genital lesion of a young person should alert the clinician that the condition may be granuloma venereum. The mistaken diagnosis of cancer in the penis based on histology alone in this part of the country where granuloma venereum is endemic has cost many a patient a cruel unjustifiable ablation of the most important member of his anatomy. We have records in many instances where such tragedies have happened". 75

(3) The dermis shows a dense infiltrate of plasma cells. Polymorphonuclear neutrophils are usually scanty but may cluster near the epidermis in microabscesses. Lymphocytes are notably rare. The number of eosinophils varies. Endothelial cells are often swollen. Fibrosis and oedema are prominent in some patients.

\section{Other diagnostic methods}

Skin tests and complement fixation tests have been reported by a number of authors (tables $3 \& 4$ ).
Although sensitivity and specificity were encouraging they have not become established adjuncts to the diagnosis of donovanosis. The sensitivity of the complement fixation test is much lower in early stages of the illness; Goldberg et al reported a sensitivity of only $43 \%$ in seven patients with lesions of two weeks or less duration. ${ }^{79}$ The specificity of the humoral responses first reported by Anderson $^{38}$ is rendered questionable by the findings of Rake and others who demonstrated that similar responses could be obtained in patients with other types of chronic ulcer or by substituting a klebsiella antigen for calymmatobacterium antigen. ${ }^{8485}$ More recently, studies from South Africa have shown that tissue sections from donovanosis lesions, after incubation with serum from patients with donovanosis, show positive immunofluorescence ${ }^{86}$ and immunoperoxidase reactions. ${ }^{87}$

\section{Co-existing diseases}

Of sexually transmitted diseases, syphilis is most often reported in conjunction with donovanosis (see above, Differential Diagnosis). In the older literature several fatal cases of donovanosis were shown to have concomitant tuberculosis. ${ }^{88-90}$ There are a substantial number of reports of squamous carcinoma being 
Table 3 Complement fixation studies in donovanosis

\begin{tabular}{|c|c|c|c|c|c|c|}
\hline \multicolumn{2}{|c|}{ No of patients } & \multicolumn{2}{|c|}{ Controls } & \multirow[b]{2}{*}{ Sensitivity (\%) } & \multirow[b]{2}{*}{ Specificity (\%) } & \multirow[b]{2}{*}{ Reference } \\
\hline+ & - & + & - & & & \\
\hline $\begin{array}{r}12 \\
1 \\
21 \\
22 \\
50 \\
136 \\
27\end{array}$ & $\begin{array}{r}3 \\
0 \\
4 \\
2 \\
8 \\
15 \\
1\end{array}$ & $\begin{array}{r}1 \\
1 \\
4 \\
7 \\
12 \\
0 \\
0\end{array}$ & $\begin{array}{r}18 \\
19 \\
27 \\
57 \\
78 \\
158 \\
5\end{array}$ & $\begin{array}{r}80 \\
100 \\
84 \\
92 \\
86 \\
90 \\
96\end{array}$ & $\begin{array}{r}95 \\
95 \\
87 \\
90 \\
87 \\
100 \\
100\end{array}$ & $\begin{array}{l}38 \\
45 \\
76 \\
40,77 \\
78 \\
79 \\
80\end{array}$ \\
\hline
\end{tabular}

Table 4 Skin tests in donovanosis

\begin{tabular}{|c|c|c|c|c|c|c|}
\hline \multicolumn{2}{|c|}{ No of patients } & \multicolumn{2}{|c|}{ Controls } & \multirow[b]{2}{*}{ Sensitivity (\%) } & \multirow[b]{2}{*}{ Specificity (\%) } & \multirow[b]{2}{*}{ Reference } \\
\hline+ & - & + & - & & & \\
\hline $\begin{array}{l}24 \\
10 \\
10 \\
17 \\
40\end{array}$ & $\begin{array}{l}1 \\
0 \\
6 \\
2 \\
0\end{array}$ & $\begin{array}{l}8 \\
2 \\
7\end{array}$ & $\begin{array}{l}11 \\
18 \\
21\end{array}$ & $\begin{array}{r}96 \\
100 \\
72 \\
89 \\
100\end{array}$ & $\begin{array}{l}58 \\
90 \\
75\end{array}$ & $\begin{array}{l}81 \\
38 \\
40,77 \\
82 \\
83\end{array}$ \\
\hline
\end{tabular}

found either alongside active donovanosis ${ }^{91}$ or supervening on longstanding lesions, ${ }^{92}$ or developing at sites of healed lesions. ${ }^{93}$ Rajam and Rangiah found malignancy with or following 5 out of 2000 cases of donovanosis seen at their Venereal Diseases Department. ${ }^{75}$ In the Caribbean, an unusually high incidence of squamous carcinoma of the vulva has been reported in pre-menopausal women who have had donovanosis. ${ }^{9495}$

\section{The treatment of donovanosis}

Many questions remain about the ideal treatment of donovanosis. It is often stated that donovanosis has no tendency to spontaneous resolution but the extreme chronicity of the disease in some patients ${ }^{96}$ shows that the balance between healing and progression can be fine; in addition there are reports of cases that relapsed only in pregnancy ${ }^{97}$ and cases where spontaneous resolution has occurred..$^{98} 99$ In evaluating treatments for donovanosis it is important to see what proportion of patients have been confirmed by smear or biopsy and to examine the length of followup which needs to be 6-18 months if late relapses are to be detected. It is also useful to know how frequently follow-up smears have been performed while on treatment and how many days elapse before smears become negative and before lesions heal. Healing is considerably influenced by the extent of lesions and differences between groups of patients need to take this into account. The optimum duration of treatment for the individual case cannot be stated categorically. As a rule, small lesions can be cured with shorter courses of treatment. A common practice is to treat and review weekly until ulcers have healed over. Because relapse is relatively frequent extension of treatment for some time after lesions have healed has been advocated by Marmell. ${ }^{100}$ On the other hand, it has also been noted that, if antibiotics are stopped before re-epithelialisation is complete, many lesions will go on to full healing. Relapses will sometimes respond to the first drug used but may require a change of therapy. Most patients are treated as outpatients but inpatient treatment is advisable for cases with extensive or complicated lesions and when it is thought that compliance with medication is likely to be poor. For the patient's comfort, and to minimise the characteristic pungent odour, lesions should be kept clean and dry. Beyond this local measures are of questionable value.

\section{Early treatments}

Donovanosis is of some interest historically as it was one of the few bacterial infections for which effective and specific therapy was available in the preantibiotic era. Large numbers of patients were successfully treated with intravenous potassium antimony tartrate (tartar emetic) and related trivalent antimonials. Relapses were fairly frequent and resistant cases could prove exceedingly difficult to manage. Antimonials remained the mainstay of treatment until the advent of streptomycin. The only other treatments which achieved any measure of success before antibiotics came in were surgical excision of lesions, ${ }^{101}$ diathermic fulguration, ${ }^{102}$ local treatment with podophyllin, ${ }^{103}$ ultra-violet radiation $^{104}$ and radiotherapy. ${ }^{105}$

\section{Antibiotics}

Many antibiotics have been employed in the treat- 
ment of donovanosis. Their efficacy has been assessed mostly in open trials. Direct comparisons have rarely been reported and none has been randomised. In vitro data on the sensitivities of Calymmatobacterium granulomatis to antibiotics are very scanty ${ }^{4106107}$ and have not been reported since 1951 . Thus treatment has to be empirical, taking into account the responsiveness of donovanosis in the area concerned to the antibiotics available. Donovanosis appears to respond best to lipid soluble antibiotics, such as chloramphenicol, erythromycin, lincomycin, quinolones and tetracyclines, which combine activity against gram negative bacilli with an ability to reach high intracellular to extracellular concentration ratios. Individual cases of resistance to most of these antibiotics have been reported and multiply resistant cases also occur.$^{80}{ }^{108}$ (A detailed table of the results of all the trials cited in the following section is available from the author on request.)

\section{Ampicillin ${ }^{59}$ 109-112}

Results with this drug were excellent in Vietnam ${ }^{110}$ and in one other report ${ }^{109}$ but very poor in other reports. ${ }^{5911112}$ On the available evidence ampicillin cannot be recommended as first line treatment for donovanosis.

\section{Chloramphenico ${ }^{113-122}$ and thiamphenicol ${ }^{123}$}

Chloramphenicol is highly effective in donovanosis, treatment failures being very rare. The use of this drug for conditions that are generally not lifethreatening is often condemned outright. It is possible, however, that the risks of aplastic anaemia from chloramphenicol are lower for some ethnic groups and that the risks in relation to those from cotrimoxazole and tetracyclines have been rather overemphasised. ${ }^{124}$ It has been used as the standard treatment for donovanosis for many years in Papua New Guinea where no serious adverse effects have been reported (author's observations). A recent report has suggested that thiamphenicol is of comparable efficacy. ${ }^{123}$ It has the advantage of once daily administration. Intracellular to extracellular concentration ratios are lower than for chloramphenicol $^{125}$ which may partly explain why serious marrow toxicity has not been reported with thiamphenicol. ${ }^{126}$

\section{Cotrimoxazole ${ }^{127-130}$}

Cotrimoxazole was introduced in India in 1962. ${ }^{127}$ Good initial results were confirmed in a later large series. ${ }^{128}$ Two failures with Septrin are reported by Pradinaud et $a^{98}$.

\section{Macrolides and lincosamines}

Published reports with erythromycin ${ }^{131-135}$ are few in number but mostly report excellent results. Car- bomycin, ${ }^{136} 137$ a macrolide similar to erythromycin is now obsolete. Lincomycin ${ }^{110} 135$ which has excellent intracellular penetration has been found useful but experience with it is very limited. Clindamycin which is now often preferred to lincomycin has not been evaluated in donovanosis.

\section{Streptomycin ${ }^{80122130138-159}$ and gentamicin ${ }^{80160}$}

There is extensive experience with streptomycin in donovanosis. High doses (eg $4 \mathrm{~g}$ daily) were often employed and reported toxicity with short courses was low. It is now felt generally unsafe to exceed a daily dose of $2 \mathrm{~g}$. Streptomycin has now generally been superseded by other drugs though it remains a candidate for combination therapy ${ }^{130}$ and its use in India continued until fairly recently. ${ }^{159}$ Relapse rates with streptomycin appear to be rather higher than with alternatives. Gentamicin has been rarely used in donovanosis. ${ }^{80160}$ Results are satisfactory but appear to have no special advantages over alternatives.

\section{Tetracyclines ${ }^{97116122}$ 161-185}

Many antibiotics of this class have been employed and they are felt by many to be the treatment of choice for donovanosis. ${ }^{186}$ The results are usually excellent although well-documented individual cases of resistance have been reported ${ }^{96187188}$ and tetracycline appeared to be ineffective against donovanosis in Vietnam. ${ }^{189}$ Experience with newer tetracyclines such as minocycline and doxycycline is much less extensive but available reports suggest they are of value. $^{171-173}$

\section{Other antibiotics}

Success with small series or single patients has been reported with phosphomycin ${ }^{190}$ and cycloserine.$^{191}$ Of particular interest are the excellent recent results obtained with norfloxacin in India. ${ }^{192}$ Sulphonamides, with the exception of a couple of reports ${ }^{193} 194$ have not been found useful in donovanosis other than as a component of cotrimoxazole. Drugs without effect in donovanosis are penicillin ${ }^{195-197}$ and spectinomycin (when given as a single dose).$^{198}$ Penicillin has never been evaluated at full dosage. It has been shown to have some activity in vitro ${ }^{107}$ and does have some value in clearing secondary contaminants. ${ }^{196}$ The use of cephalosporins in donovanosis has not been reported, despite their activity against gram negative organisms.

\section{Antibiotic combinations 130135173199200}

Antibiotics in combination have rarely been evaluated in donovanosis. The rationale for their use is sound, particularly in more serious cases or in pregnancy. Combinations that have been used include chloramphenicol and tetracycline, ${ }^{199}$ and streptomycin with penicillin, tetracycline or chloramphenicol..$^{130173200}$ Streptomycin with tetracy- 
cline showed no advantages in a comparison with cotrimoxazole. ${ }^{130}$ Lincomycin with erythromycin gave good results in pregnant aboriginal women in Australia. ${ }^{135}$

\section{Donovanosis in pregnancy}

The lesions of donovanosis show a marked tendency to proliferate ${ }^{201}$ or recur ${ }^{97}$ in pregnancy, and diminished responsiveness to standard antibiotic therapy. The use of cotrimoxazole, tetracyclines, streptomycin, erythromycin estolate and chloramphenicol in pregnancy is of questionable safety. Ashdown et al have reported favourably with lincomycin and erythromycin. ${ }^{135}$ The transplacental side-effects of doxycycline on teeth appear to be substantially less than those with tetracycline ${ }^{202}$ though there is the additional concern of hepatotoxicity to pregnant women to consider. ${ }^{203}$ In Papua New Guinea chloramphenicol has been used in many pregnant women with donovanosis without reported adverse effects (author's observations).

There are additional considerations in the treatment of donovanosis in pregnancy. There is good evidence that delivery through a cervix infected with untreated donovanosis predisposes to haematogenous dissemination of the disease, ${ }^{204}$ not infrequently with fatal results. ${ }^{205}$ If a cervical lesion of donovanosis is discovered during pregnancy it may be possible to administer treatment and effect healing before labour ${ }^{137}$ but where the diagnosis is made late or there are doubts about the effectiveness of treatment, elective Caesarian should be considered. ${ }^{206}$ The neonate too is at risk of acquiring donovanosis when exposed to untreated lesions of donovanosis though this is extremely rare.$^{207}$ It would be wise to treat any neonate so exposed with careful cleansing of the ears, umbilicus and genitalia and to a course of prophylactic antibodies.

\section{Treatment of sequelae and complications Surgery}

Successful eradication of $C$. granulomatis with antibiotics can still leave many patients with substantial genital deformities. In women particularly, elephantiasis, strictures and fistulae may require surgery. Parkash et al have emphasised the considerable benefits that these patients may get from modern plastic surgical techniques. ${ }^{208}$ Surgery on active lesions carries a distinct risk of spreading the infection $^{209-211}$ and so should await antibiotic treatment or, at least, be carried out with antibiotic cover. Extragenital lesions sometimes prove refractory to antibiotic treatment and antibiotics combined with surgical curettage may give the best results. ${ }^{80}$ Robinson et al were successful in curing surgically 10 patients in whom all chemotherapy had failed. ${ }^{101}$

\section{Intrapelvic donovanosis}

The case fatality rates for donovanosis involving the cervix of $5 \cdot 2 \%$ reported by Arnell and Potekin ${ }^{212}$ and $14.3 \%$ reported by Pund and McInnes ${ }^{205}$ indicate the great importance of recognising and giving adequate treatment to patients with this particular form of the disease. The close similarity of isolated cervical lesions of donovanosis to carcinoma has frequently resulted in delays in diagnosis. ${ }^{213}$ Involvement by donovanosis of the uterus, tubes and ovaries can mimic pelvic inflammatory disease or pelvic malignancy. Reported clinical findings include tuboovarian abscess, frozen pelvis, hard masses and hydronephrosis. ${ }^{214-216}$ Such lesions can resolve to a remarkable degree on antibiotic treatment alone and surgical exploration, while required for drainage of collections, carries the risk of disseminating the infection if unwittingly carried out without suitable antibiotic cover. ${ }^{211}$

\section{Disseminated donovanosis}

This life-threatening complication of donovanosis is strongly associated with pregnancy (see above, Donovanosis in pregnancy). It manifests most commonly as lytic bone lesions which may spread into and ulcerate the overlying skin. Lesions of lung, liver and spleen have also been recorded. ${ }^{173} 217218$ Antibiotic treatment should suffice though combination therapy may give better results. ${ }^{173}$

\section{Secondary infection}

In the older literature on donovanosis are many reports of chronic indolent lesions of the vulva suddenly changing course with rapid and extensive tissue destruction leading to the formation of a large cloaca, haemorrhage, abdominal perforation and death. ${ }^{29} 7289$ It is generally felt that this complication results from complicating fusospirochaetal infection. ${ }^{72}$ Lesions displaying any tendency to behave in this way should be treated with vigorous extended antibiotic regimens, and, in cases with necrotising fasciitis, surgical debridement.

\section{Donovanosis and AIDS}

There is already evidence that donovanosis may behave differently in patients with AIDS. An early report describes donovanosis appearing with typical clinical lesions in two AIDS patients but failing to respond to extended courses of treatment with combinations of cotrimoxazole, tetracycline and thiamphenicol. ${ }^{219}$ The explanation for these failures is likely to lie not so much in primary antibiotic resistance but in inability of antibiotics to clear the infection in the presence of immune deficiency. If immune suppression is an important factor in the observed association between haematogenous dissemination of donovanosis and pregnancy, then this rare complication of donovanosis may begin to appear more frequently as AIDS spreads to areas endemic for donovanosis. In South Africa it has been noted that patients with donovanosis often remain 
sexually active $e^{220}$ and that HIV-1 seropositivity is significantly associated with donovanosis. ${ }^{221}$

\section{Contact tracing}

Sexual partners of patients with donovanosis are frequently free of disease but the incidence of infection when sought with care can exceed $50 \% .^{28}$ Clusters of patients contracting the disease from a common source have been described. ${ }^{129} 222$ Clearly contact tracing should be attempted when possible. Blind treatment of contacts without lesions has not been advocated but counselling and follow-up should be offered.

Address for correspondence: Dr J Richens, Department of Clinical Sciences, London School of Hygiene and Tropical Medicine, Keppel St, London WCIE 7HT, UK.

1 Greenblatt RB, Barfield WE. Newer methods in the diagnosis and treatment of granuloma inguinale. $\mathrm{Br} J$ Venereal Dis 1952;28:123-8.

2 Greenblatt RB. Socioeconomic aspects of granuloma inguinale. Journal of Venereal Diseases Information 1947;28:181-3.

3 Freinkel AL. The enigma of granuloma inguinale in South Africa. S Afr Med J 1990;77:301-3.

4 O'Farrell N, Coetzee K. HIV and granuloma inguinale in Durban. S Afr Med J 1990;78:220.

5 McLeod K. Precis of operations performed in the wards of the first surgeon, Medical College O Hospital (Rio), during the year 1881. Indian Medical Gazette 1882;17:113-23.

6 Halty M. Les formes cliniques du granulome vénérien. Annales de Dermatologie et de Syphiligraphie 1933;7th series, No. 4:1101-21.

7 Sehgal VN, Sharma NL, Bhargava NC, Nayar M, Chandra $M$. Primary extragenital disseminated cutaneous donovanosis. Br J Dermatol 1979;101:353-6.

8 Spagnolo DV, Coburn PR, Cream JJ, Azadian BS. Extragenital granuloma inguinale (Donovanosis) diagnosed in the United Kingdom: a clinical, histological, and electron microscopical study. J Clin Pathol 1984;37:945-9.

9 Murugan S, Venkatram K, Renganathan PS. Vaginal bleeding in granuloma inguinale. $\mathrm{Br} J$ Venereal Dis $1982 ; 58: 200-1$.

10 Jofre ME, Webling DD, James ST. Granuloma inguinale simulating advanced pelvic cancer. Med J Aust 1976;2:866-73.

11 Bhaskar SN, Jacoway JR, Fleuchaus PT. A primary granuloma venereum of the gingiva. Oral Surg Oral Med Oral Pathol 1965;20:535-41.

12 Garg BR, Lal S, Bedi BMS, Tiwari KN, Arunthathi S. Extragenital donovanosis (with subcutaneous sinus tract). Indian Journal of Dermatology, Venereology and Leprology 1971; 44:227-8.

13 Jannach JR. Granuloma inguinale of the epididymis. $\mathrm{Br} J$ Venereal Dis 1958;34:31-3.

14 Harris R. Granuloma venereum: general discussion with report of a case of laryngeal involvement. Laryngoscope 1930;40: 707-37.

15 Lyford J, Scott RB, Johnson RW. Polyarticular arthritis and osteomyelitis due to granuloma inguinale. American Journal of Syphilis 1944;28:588-610.

16 Crane W, Kimball HS. Granuloma ventereum involving the rectum and colon. California and Western Medicine 1940; 52:177-8

17 Clarke CW. Notes on the epidemiology of granuloma inguinale. Journal of Venereal Diseases Information 1947;28:189-94.

18 Marmell $M$. Donovanosis of the anus in the male. An epidemiological consideration. $\mathrm{Br} J$ Venereal Dis 1958; 34:213-8.

19 Hanna CB. Extragenital granuloma venereum. Report of six cases of lip, oral and cutaneous involvement with review of literature. South Med J 1948;41:776-82.

20 Kirkpatrick DJ. Donovanosis (granuloma inguinale): a rare cause of osteolytic bone lesions. Clin Radiol 1970;21:101-5.

21 Greenblatt RB, Dienst RB, Pund ER, Torpin R. Experimental and clinical granuloma inguinale. JAMA 1939;113:1109-16.

22 Conyers JH, Daniels CW. The lupoid form of the so-called "groin ulceration" of this colony. British Guiana Medical Annual 1896;8:13-29.

23 Birch CA. Granuloma inguinale resembling a primary chancre. BMJ 1929;2:345.

24 Brandt R, Gatewood TS. Early diagnosis of granuloma inguinale. American Journal of Syphilis 1941;25:48-55.

25 Greenblatt RB. The newer venereal diseases. Their association and confusion with neoplastic disease. Am J Surg 1940; 49:411-9.

26 Giglioli $\mathrm{G}$. The differential diagnosis of phagedenic chancroid and granuloma inguinale. Trans $R$ Soc Trop Med Hyg 1930;23:579-89.

27 Vacca A, MacMillan LL. Anogenital lesions in women in Papua New Guinea. P N G Med J 1982;23:70-3.

28 Lal S, Nicholas C. Epidemiological and clinical features in 165 cases of granuloma inguinale. Br J Venereal Dis 1970;46: 461-3.

29 Cleland JB, Hickinbotham JR. On the etiology of ulcerative granuloma of the pudenda with clinical description and notes on treatment. J Trop Med Hyg 1909;12:143-51.

30 Werman BS, Herskowitz LJ, Olansky S, Kleris G, Sottnek FO. A clinical variant of chancroid resembling granuloma inguinale. Arch Dermatol 1983;119:890-4.

31 Verdich J. Hemophilus ducreyi infection resembling granuloma inguinale. Acta Derm Venereol 1984;64:452-5.

32 Kraus SJ, Werman BS, Biddle JW, Sottnek FO, Ewing EP Pseudogranuloma inguinale caused by Haemophilus ducreyi. Arch Dermatol 1982;118:494-7.

33 Kolmer JA. Nomenclature of the infectious inguinal granulomas. Urologic and Cutaneous Review 1941;45:689-91.

34 Schoch AG, Alexander LJ. Esthiomene, a form of granuloma inguinale. American Journal of Syphilis 1939;23:718-23.

35 Aragâo HD, Vianna G. Pesquizas sobre o granuloma venereo. Mem Inst Oszoaldo Cruz 1913;5:211-38.

36 Anderson $\mathrm{K}$. The cultivation from granuloma inguinale of a microorganism having the characteristics of Donovan bodies in the yolk sac of chick embryos. Science 1943;97:560-1.

37 Anderson K, DeMonbreun WA, Goodpasture EW. An etiologic consideration of Donovania granulomatis cultivated from granuloma inguinale (three cases) in embryonic yolk. $J$ Exp Med 1945;81:25-39.

38 Anderson K, Goodpasture EW, DeMonbreun WA. Immunologic relationship of Donovania granulomatis to granuloma inguinale. J Exp Med 1945;81:41-50.

39 Rake G, Oskay JJ. Cultural characteristics of Donovanic granulomatis. J Bacteriol 1948;55:667-75.

40 Dulaney AD, Guo K, Packer H. Donovania granulomatis: cultivation, antigen preparation, and immunological tests. $J$ Immunol 1948;59:335-40.

41 Goldberg J, Weaver RH, Packer H. Studies on granuloma inguinale. I. Bacteriologic behaviour of Donovania granulomatis. American Journal of Syphilis 1953;37:60-70.

42 Goldberg J. Studies on granuloma inguinale IV. Growth requirements of Donovania granulomatis and its relationship to the natural habitat of the organism. Br J Venereal Dis 1959;35:266-8.

43 Sheldon WH, Thebaut BR, Heyman A, Wall MJ. Osteomyelitis caused by granuloma inguinale. Report of a case with cultivation of the Donovan body in the yolk sac of the developing chick embryo. Am J Med Sci 1945;210:237-45.

44 Beveridge WIB. The action of antimony and some other bacteriostatic substances on Donovania granulomatis isolated in the chick embryo. $J$ Immunol 1946;53:215-23.

45 Jennison DB, Helwig CE, Milstone JH. Granuloma inguinale involving buttock and lymph node. Arch Dermatol Syphilol 1947;55:342-54.

46 Dienst RB, Greenblatt RB, Chen CH. Laboratory diagnosis of granuloma inguinale and studies on the cultivation of the Donovan body. American Journal of Syphilis Gonorrhea and Venereal Diseases 1948;32:301-6.

47 Thomison JB. Primary isolation of Donovania granulomatis by chick brain inoculation, and induction of cerebral miliary granulomata. Proc Soc Exp Biol Med 1951;77:557-8.

$48 \mathrm{Goldberg} J$. Studies on granuloma inguinale V. Isolation of a bacterium resembling Donovania granulomatis from the faeces of a patient with granuloma inguinale. $\mathrm{Br} J$ Venereal Dis 1962;38:99-102.

49 Cannefax GR. The technic of the tissue spread method for demonstrating Donovan bodies. Journal of Venereal Diseases Information 1948;29:210-204.

50 Donovan C. Ulcerating granuloma of the pudenda. Indian Medical Gazette 1905;40:414. 
51 Von Haam E. The laboratory diagnosis of venereal lesions. Urologic and Cutaneous Review 1938;42:412-22.

52 Packer H, Dulaney AD. Diagnostic tests in granuloma inguinale. American Journal of Syphilis 1949;33:68-75.

53 Marmell M, Santora E. Donovanosis - granuloma inguinale. Incidence, nomenclature, and diagnosis. American Journal of Syphilis 1950;34:83-90.

54 De Boer A-L, De Boer F, Van der Merwe JV. Cytologic identification of Donovan bodies in granuloma inguinale. Acta Cytol 1984;28:126-8.

55 Leiman G, Markowitz S, Margolius KA. Cytologic detection of cervical granuloma inguinale. Diagn Cytopathol 1986;2: 138-43.

56 Golfo EB, Galindo LM. Diagnosis of an unusual abdominal presentation of granuloma inguinale by fine needle aspiration cytology. Acta Cytol 1990;34:570-2.

57 Packer H, Turner HB. Granuloma inguinale of the vagina and cervix uteri with bone metastases. JAMA 1948;136:327-9.

58 Davis CM, Collins C. Granuloma inguinale: an ultrastructural study of Calymmatobacterium granulomatis. J Invest Dermatol 1969;53:315-21.

59 Davis M. Granuloma inguinale. A clinical, histological, and ultrastructural study. $J A M A$ 1970;211:632-6.

60 Dodson RF, Fritz GS, Hubler WR, Rudolph AH, Knox JM, Chu L W-F. Donovanosis: a morphologic study. J Invest Dermatol 1974;62:611-4.

61 Kuberski T, Papadimitriou JM, Phillips P. Ultrastructure of Calymmatobacterium granulomatis in lesions of granuloma inguinale. J Infect Dis 1980;142:744-9.

62 Chandra M, Jain AK, Ganguly DD, Sharma AK, Bhargava NC. An ultrastructural study of donovanosis. Indian J Med Res 1989;90:158-64.

63 O'Farrell N, Hoosen AA, Coetzee K, Van den Ende J. A rapid stain for the diagnosis of granuloma inguinale. Genitourin Med 1990;66:200-1.

64 Dienst RB, Chen $\mathrm{CH}$, Greenblatt RB. Granuloma inguinale. Urologic and Cutaneous Review 1949;53:537-43.

65 Pund ER, Greenblatt RB. Specific histology of granuloma inguinale. Arch Pathol 1937;23:224-9.

66 Jain AK, Chandra M, Ganguli DD, Bhargava NC. Utility of semithin sections in the diagnosis of donovanosis. Indian $J$ Med Res 1989;90:270-4.

67 Sehgal VN, Jain MK. Tissue section donovan bodiesidentification through slow Giemsa (overnight) technique. Dermatologica 1987;174:228-31.

68 Galloway J. Ulcerating granuloma of the pudenda: a report on a recently described form of ulceration occurring in the West Indies. Br J Dermatol 1897;9:133-47.

69 D'Aunoy $R$, Von Haam $E$. The pathology of granuloma venereum. Am J Pathol 1938;14:39-47.

70 Nayar M, Chandra M, Saxena HMK, Bhargava NC, Sehgal VN. Donovanosis-a histopathological study. Indian J Pathol Microbiol 1981;24:71-6.

71 Sehgal VN, Shyamprasad AL, Beohar PC. The histopathological diagnosis of donovanosis. $\mathrm{Br} J$ Venereal Dis 1984;60:45-7.

72 D'Aunoy R, Von Haam E. Granuloma inguinale. Am J Trop Med 1937;17:747-63.

73 Philpott OS. Pseudoepitheliomatous hyperplasia due to granuloma inguinale. Arch Dermatol Syphilol 1947;56:669-75.

74 Beerman $\mathrm{H}$, Sonck CE. The epithelial changes in granuloma inguinale. American Journal of Syphilis Gonorrhea and Venereal Diseases 1952;36:501-10.

75 Rajam RV, Rangiah PN. Granuloma venereum and its relationship to epidermoid carcinoma. Indian $J$ Venereal Diseases and Dermatology 1953;19:1-19.

76 Dulaney AD, Packer $H$. Complement fixation studies with pus antigen in granuloma inguinale. Proc Soc Exp Biol Med 1947;65:254-6.

77 Packer H, Dulaney AD. Diagnostic tests in granuloma inguinale. American Journal of Syphilis 1949;33:68-75.

78 Dunham $W$, Rake G. Cultural and serologic studies on granuloma inguinale. American Journal of Syphilis 1948; 32:145-9.

79 Goldberg J, Weaver RH, Packer H, Simpson WG. Studies on granuloma inguinale. II. The complement fixation test in the diagnosis of granuloma inguinale. American Journal of Syphilis 1953;37:71-6.

80 Maddocks I, Anders EM, Dennis E. Donovanosis in Papua New Guinea. Br J Venereal Dis 1976;52:190-6.

81 Pandalai NG, Nair VG. Sensitisation and anti-body production in granuloma genito-inguinale. Indian J Med Res 1934; 21:731-4.
82 Kornblith BA. An intradermal reaction as an aid in the diagnosis of granuloma inguinale. $N Y$ Stat $J$ Med $1944 ; 44: 2476-8$.

83 Chen $\mathrm{CH}$, Dienst RB, Greenblatt RB. Skin reaction of patients to Donovania granulomatis. American Journal of Syphilis 1949;33:60-64.

84 Rake G. The antigenic relationships of Donovania granulomatis (Anderson) and the significance of this organism in granuloma inguinale. American Journal of Syphilis Gonorrhea and Venereal Diseases 1948;32:150-8.

85 Packer H, Goldberg J. Complement fixation studies in granuloma inguinale. Am J Trop Med 1950;30:387-95.

86 Freinkel AL. Granuloma inguinale of cervical lymph nodes simulating tuberculous lymphadenitis: two case reports and review of published reports. Genitourin Med 1988;64:339-43.

87 Afrika DJ. Demonstration of Donovan bodies in lesions of granuloma inguinale using an immunoperoxidase method. Medical Technology in South Africa 1990;4:294-6.

88 Kuhn. Pathologisch-anatomischer Befund bei sieben Fällen von ,venerischem Granulom" in Neu-Guinea. Charité Annalen 1906;30:427-36.

89 Watsford SD, Alderman LW. Granuloma inguinale. Med J Aust 1953;2:50-2.

90 Fox H. Granuloma inguinale: its occurrence in the United States. A report of fifteen cases observed in New York. JAMA 1926;87:1785-91.

91 Stewart DB. The gynecological lesions of lymphogranuloma venereum and granuloma inguinale. Med Clin N Am 1964;33:60-4.

92 Alexander LJ, Shields TL. Squamous cell carcinoma of the vulva secondary to granuloma inguinale. Archives of Dermatology and Syphilology 1953;67:395-402.

93 Sengupta BS. Vulval cancer following or co-existing with chronic granulomatous diseases of vulva. Trop Doct 1981; 11:110-4.

94 Hay DM, Cole FM. Postgranulomatous epidermoid carcinoma of the vulva. Am J Obstet Gynecol 1970;108:479-84.

95 Sengupta BS. Vulvar carcinoma in premenopausal Jamaican women. Int J Gynaecol Obstet 1980;17:526-30.

96 Graney MJ, Bodon GR. Granuloma inguinale with several unique features. N Y Stat J Med 1976;76:433-4.

97 Marmell M, Prigot A. Tetracycline (Tetracyn) in the treatment of donovanosis. Harlem Hospital Bulletin 1955;8: 9-11.

98 Pradinaud R, Grosshans E, Basset A, Bertin C. Etude de 24 cas de donovanose en Guyane Française. Bull Soc Pathol Exot Filiales 1981;74:30-36.

99 Thierfelder MU. The control of granuloma venereum among the Marindinese in Dutch South New Guinea. Mededelingen van den Dienst der Volksgezondheid in Nederlandsch-Indie $1928 ; 17: 393-423$

100 Marmell M, Prigot A. Donovanosis: diagnosis and treatment. Harlem Hospital Bulletin 1960;13:1-13.

101 Robinson HM, Robinson HM Jr, Shelley HS, Mays HB. The treatment of granuloma inguinale. South Med J 1942;35 889-95.

102 Greenwood FG. The treatment of granuloma inguinale by diathermic fulguration. An analysis of twenty-two cases. $\mathrm{Br} J$ Radiol 1931;4:489-98.

103 Tomskey GC, Vickery GW, Getzoff PL. The successful treatment of granuloma inguinale, with special reference to the use of podophyllin. $J$ Urol 1942;48:401-6.

104 Murray AJ. Granuloma inguinale. Notes on a chronic case successfully treated with ultra-violet radiations. West African Medical Journal 1932;6:31.

105 Araujo HC. O granuloma venereum e a roentgentherapia. Brazil Medico 1915;29:201-2.

106 Rake G, Dunham W. Action of disinfectant, chemotherapeutic, and antibiotic agents on the organism of granuloma inguinale. American Journal of Syphilis 1947;31:610-7.

107 Chen CH, Dienst RB, Greenblatt RB. Antibiotics versus Donovania granulomatis. American Journal of Syphilis 1951, 35:383-92.

108 Rangiah PN. Granuloma venereum-a retrospective study. Indian Journal of Dermatology and Venereology 1962;28:172-9.

109 Thew MA, Swift JT, Heaton CL. Ampicillin in the treatment of granuloma inguinale. JAMA 1969;210:866-7.

110 Breschi LC, Goldman G, Shapiro SR. Granuloma inguinale in Vietnam: successful therapy with ampicillin and lincomycin. Journal of the American Venereal Diseases Association 1975;1:118-20.

111 Marchand C, Fayol D, Gaboriaux MC, Thivolet J. La donovanose. A propos d'un nouveau cas de granuloma inguinal en 
France. Ann Med Intern 1986;137:656-9.

112 Johnson SH, Cherubin C. Case report. Infectious Diseases Newsletter 1991;10:14-15.

113 Greenblatt RB, Wammock VS, Dienst RB, West RM. Chloromycetin in the therapy of granuloma inguinale. $J$ Med Assoc Ga 1949;38:206-8.

114 Greenblatt RB, Wammock VS, Dienst RB, West RM. Chloromycetin in the therapy of granuloma inguinale. $\mathrm{Am} J$ Obstet Gynecol 1950;59:1129-33.

115 Robinson RCV. Newer antibiotics in the treatment of venereal diseases. American Journal of Syphilis 1950;34:273-88.

116 Robinson RCV, Cronk B. Granuloma inguinale: further observations on results of treatment with aureomycin and chloramphenicol. American Journal of Syphilis 1951;35: 378-82.

117 Harb FW, Simpson WG, Wood CE. Intramuscular injections of chloromycetin in the treatment of granuloma inguinale. Journal of Venereal Diseases Information 1951;32:177-81.

118 Zises M, Smith GC. Nine cases of granuloma inguinale treated with chloromycetin. American Journal of Syphilis 1951; 35:294-6.

119 Robinson RCV, Wells TL. Intramuscular chloramphenicol in the treatment of gonorrhea and granuloma inguinale. American Journal of Syphilis 1952;36:264-8.

120 Rajam RV, Rangiah PN. A short note of the therapy of venereal granuloma with Aureomycin and chloramphenicol. Indian Journal of Venereal Diseases and Dermatology 1952;18:150-2.

121 Olansky S, Harb FW, Wood CE, Rambo DS. Intramuscular chloromycetin (chloramphenicol) in the treatment of venereal disease. American Journal of Syphilis 1953;34:253-8.

122 Zigas V. A donovanosis project in Goilala (1951-1954). P N G Med J 1971;14:148-9.

123 Jardim ML, Melo ZD. Tratamento da donovanose com o tianfenicol. Anais Brasileiros de Dermatologia e Sifilografia 1990;65:93-4.

124 Sheba C. Risks of chloramphenicol? Lancet 1967;i:1007.

125 McLeod TF, Manyan DR, Yunis AA. The cellular transport of chloramphenicol and thiamphenicol. J Lab Clin Med 1977; 90:347-53.

126 Franceschinis R. Drug utilization data for chloramphenicol and thiamphenicol in recent years. In: Najean $Y$, Tognoni $G$ Yunis AA, eds. Safety problems related to chloramphenicol and thiamphenicol. New York: Raven Press, 81-9.

127 Garg BR, Lal S, Sivamani S. Efficacy of cotrimoxazole in donovanosis. Br J Venereal Dis 1978;54:348-9.

$128 \mathrm{Lal}$ S, Garg BR. Further evidence of the efficacy of cotrimoxazole in granuloma venereum. $\mathrm{Br} J$ Venereal Dis 1980;56:412-3.

129 Rosen T, Tschen JA, Ramsdell W, Moore J, Markham B. Granuloma inguinale. J Am Acad Dermatol 1984;11:433-7.

130 Latif AS, Mason PR, Paraiwa E. The treatment of donovanosis (granuloma inguinale). Sex Transm Dis 1988;15:27-9.

131 Robinson HM, Cohen MM. Treatment of granuloma inguinale with erythromycin. J Invest Dermatol 1953;20:407-9.

132 Cordice JWV, Avecilla M, Marmell M, Shidlovsky BA, Prigot A. Erythromycin: a preliminary report on its use in certain venereal diseases. Antibiotics Annual 1953-4;1:480-4.

133 Alexander LJ, Schoch AG. Erythromycin in venereal diseases. American Journal of Syphilis 1954;38:107-9.

134 Ghosh S, Ghosh R. Donovanosis treated with erythromycin parenterally. Report of first case. $B r J$ Venereal Dis 1959;35:260-1

135 Ashdown LR, Kilvert GT. Granuloma inguinale in Northern Queensland. Med J Aust 1979;1:146-8.

136 Whitaker JC, Prigot A, Marmell M, Morgan EG. Magnamycin-a new antibiotic. A preliminary report on its use in gonorrhea, lymphogranuloma venereum, and donovanosis. American Journal of Syphilis 1953;37:466-70.

137 Adams JQ Packer H. Granuloma inguinale of the cervix. South Med J 1955;48:27-33.

138 Barton RL, Craig RM, Schwemlein GX, Bauer TJ. Granuloma inguinale treated with streptomycin. Arch Dermatol Syphilo 1947;56:1-6.

139 Greenblatt RB, Kupperman HS, Dienst RB. Streptomycin in the therapy of granuloma inguinale. Proc Soc Exp Biol Med $1947 ; 64 \cdot 389-90$

140 Greenblatt RB, Dienst RB, Kupperman HS, Reinstein BS. Granuloma inguinale: streptomycin therapy and research. $J$ Venereal Diseases Information 1947;28:183-8.

141 Chen CH, Greenblatt RB, Dienst RB. Recent observations on granuloma inguinale with report on streptomycin therapy. Archives of Dermatology Syphilology 1948;58:703-15.

142 Chen CH, Greenblatt RB, Dienst RB. Streptomycin in the therapy of granuloma inguinale. $J$ Med Assoc Ga 1948;37: 373-5.

143 Sauer GC, Sackett AP, Kuhl IW. Streptomycin in the treatment of granuloma inguinale. $W V$ Med $J 1948 ; 44: 218-21$.

144 Hirsh HL, Taggart SR. The treatment of granuloma inguinale with streptomycin. American Journal of Syphilis 1948;32: 159-64.

145 Kupperman HS, Greenblatt RB, Dienst RB. Streptomycin in the therapy of granuloma inguinale. JAMA 1948;136:84-9.

146 Zimmerman RJ, Smith GC. Granuloma inguinale-report of 85 cases treated with streptomycin. J S C Med Assoc 1948; 44:267-8.

147 Thompson RG, White CB, Hailey H. Granuloma inguinale. Report of three cases treated with massive doses of streptomycin. South Med J 1948;41:994-7.

148 Marshak LC, Rodriguez J. Granuloma inguinale. Treatment with streptomycin. JAMA 1948;137:1293-7.

149 Marshak L, Barton RL, Bauer TJ. Granuloma inguinale. A review of the literature and a report of ninety-seven cases with a note on streptomycin therapy. Arch Dermatol Syphilol 1948;57:858-67.

150 Jacoby A, Rosenthal T, Sobel N. Ambulatory treatment of granuloma inguinale with streptomycin. American Journal of Syphilis 1949;33:76-9.

151 Sondag RF, Henry JF, Batsche J. Streptomycin therapy in granuloma inguinale. J Fla Med Assoc 1949;36:355-9.

152 Stewart JJ, Laur WE. Streptomycin therapy of granuloma inguinale. American Journal of Syphilis 1949;33:65-7.

153 Rajam RV, Serma JS. A short note on streptomycin therapy of venereal granuloma. Indian Journal of Venereal Diseases and Dermatology 1949;16:71-80.

154 Samitz MH, Horvath PN, Mori PP, Beerman H. Streptomycin therapy of chronic granuloma inguinale. J Invest Dermatol 1949;12:85-93.

155 Freed CR, Kern FM. Treatment of granuloma inguinale with streptomycin. Am J Obstet Gynecol 1950;59:195-99.

156 Pariser H, Goldberg SZ, Mitchell GH. Streptomycin treatment of granuloma inguinale. Arch Dermatol and Syphilol 1950;62:261-4.

157 Hoge RH, Salzberg AM. Granuloma inguinale of the cervix uteri and vulva treated with streptomycin. Am J Obste Gynecol 1950;60:911-3.

158 Rajam RV, Rangiah PN. Further observations on streptomycin therapy in venereal granuloma. Indian J Venereal Diseases and Dermatology 1952;18:1-8.

$159 \mathrm{Lal} \mathrm{S}$. Continued efficacy of streptomycin in the treatment of granuloma inguinale. Br J Venereal Dis 1971;47:454-5.

160 Normand P, Renault J, Becker JM, Millea JM, Doury J-C. Une affection exotique sexuellement transmise: la donovanose. Med Trop (Mars) 1982;42:54-7.

161 Wright LT, Sanders M, Logan MA, Prigot A, Hill LM. The treatment of lymphogranuloma venereum and granuloma inguinale in humans with aureomycin. Ann $N Y$ Acad $S c i$ 1948;51:318-30.

162 Greenblatt RB, Wammock VS, West RM, Dienst RB, Chen $\mathrm{CH}$. Oral aureomycin in the therapy of granuloma inguinale. American Journal of Syphilis 1949;33:593-8.

163 Robinson RCV, Elmendorf DF, Zheutlin HEC. Aureomycin in the treatment of granuloma inguinale. American Journal of Syphilis 1949;33:389-96.

164 Hill LM, Wright LT, Prigot A, Logan MA. Aureomycin in granuloma inguinale. JAMA 1949;141:1047-50.

165 Prigot A, Wright LT, Logan MA, DeLuca FR. Anorectogenital lymphogranuloma venereum and granuloma inguinale treated with aureomycin. N Y Stat J Med 1949;49:1911-7.

166 Wammock VS, Greenblatt RB, Dienst RB, Chen C, West RM. Aureomycin in the treatment of granuloma inguinale and lymphogranuloma venereum. J Invest Dermatol 1950;14: 427-34.

$167 \mathrm{Zises} M$, Smith GC. Granuloma inguinale and its treatment with oral aureomycin. Arch Dermatol Syphilol 1950;62:642-7.

168 Marmell M, Prigot A. The therapeutic value of demethylchlortetracycline in gonorrhoea, lymphogranuloma venereum, and donovanosis. Antibiotics Annual 1959-60;7:457-61.

169 Marmell M, Prigot A. Granuloma inguinale (donovanosis) treated with methacycline. N Y Stat J Med 1964;64:804-5.

170 Santos JM, Coelho WD, Coelho NG, Junqueira MD. Metaciclina na terapêutica da donovanose (granuloma venéreo) O Hospital (Rio) 1968;74:271-8.

171 Velasco JE, Miller E, Zaias N. Minocycline in the treatment of venereal disease. JAMA 1972;22:1323-5.

172 Cordero FA. Evaluación clinica de la minociclina en der- 
matologia y en venéreología. Revista del Colegio de Médicos (Buenos Aires) 1972;23:149-54.

173 Cordero FA. Granuloma venéreo. Su manifestación clínica en genitales y otras partes del organismo. Med Cutan Ibero Lat Amer 1975;3:125-32.

174 Marmell M, Prigot A. Oleandomycin in the treatment of donovanosis. Antibiotic Medicine 1956;3:263-7.

175 Schoch AG, Alexander LJ. Terramycin in the control of venereal diseases. Ann N Y Acad Sci 1950;53:459-60.

176 Hendricks FD, Greaves AB, Olansky S, et al. Terramycin in the treatment of venereal disease. JAMA 1950;143:4-5.

177 Greenblatt RB, Barfield WE, Dienst RB, West RM. Terramycin in treatment of granuloma inguinale. Journal of Venereal Diseases Information 1951;32:113-15.

178 Wright LT, Prigot A, DiLorenzo JC, Whitaker JC, Marmell $M$. Oral terramycin in the rapid treatment of gonorrhea and other venereal diseases. American Journal of Syphilis 1951;35:490-5.

179 Niedelman ML, Pierce HE, Hoffstein LD, Matteucci WV. Terramycin in the treatment of chancroid, lymphogranuloma venereum, and granuloma inguinale. American Journal of Syphilis 1951;35:482-7.

180 Whitaker JC, Wright LT, Beinfield MS, Wilkinson RS, Marmell M. Oral terramycin in granuloma inguinale. Antibiotics and Chemotherapy 1951;1:208-10.

181 Dunlop EM, Robinson RCV. Intravenous terramycin in the treatment of early syphilis and granuloma inguinale. American Journal of Syphilis 1954;38:24-9.

182 Maynard AD, Prigot A, Marmell M. The effect of tetracycline hydrochloride in lymphogranuloma venereum and donovanosis. American Journal of Syphilis 1954;38:606-8.

183 Rajam RV, Rangiah PN, Sowmini CN, Krishnamoorthy N. Tetracyclene (Achromycin) in venereal diseases. The Antiseptic 1956;53:9-19.

184 Marmell M, Prigot A. The use of tetracycline phosphate complex in a venereal disease clinic. Antibiotic Medicine and Clinical Therapy 1959;2:111-6.

185 Kerdel-Vegas F, Convit J, Soto JM. Treatment of granuloma inguinale with triacetlyoleandomycin. Arch Dermatol 1961;84:248-55.

186 World Health Organisation. Nongonococcal urethritis and other sexually transmitted diseases of public health importance. Technical Report Series No. 660. 1981.

187 Pariser RJ. Tetracycline-resistant granuloma inguinale. Arch Dermatol 1977;113:988.

188 Masouyé I, Bergues JP, Mérot Y, Chavaz P, Harms M. Donovanose résistante à la doxycycline: à propos d'une observation. Dermatologica 1987;175:104-7.

189 Shapiro SR, Breschi LC. Venereal disease in Vietnam: clinical experience at a major military hospital. Milit Med 1974;139:374-9.

190 Fujiwara S, Honda $\mathrm{T}$, Shinkai $\mathrm{H}$ et al. A case of donovanosis in Japan. J Dermatol 1987;14:375-7.

191 Marmell M, Prigot A. Clinical trial of cycloserine in donovanosis, lymphogranuloma venereum, and gonorrhea. Antibiotics Annual 1955-6:3:154-7.

192 Ramanan C, Sarma PSA, Ghorpade A, Das M. Treatment of donovanosis with norfloxacin. Int J Dermatol 1990;29:298-9.

193 Ross AOF. Granuloma venereum treated with M\&B 693. Lancet 1939;1:26.

194 Earle KV. Sulphanilamide in the treatment of ulcerative granuloma. Trans $R$ Soc Trop Med Hyg 1940;34:261-8.

195 Nelson RA. Penicillin in the treatment of granuloma inguinale. Journal of Syphilis 1944;23:611-9.

196 Turner FB. A report of the treatment of seven cases of granuloma venereum with penicillin. Med J Aust 1945;2: 366-7.

197 Haserick JR. A failure of penicillin in the treatment of granuloma inguinale. Arch Dermatol 1945;52:182.

198 O'Farrell N. Failure of single dose spectinomycin in granuloma inguinale (donovanosis). Trans $R$ Soc Trop Med Hyg 1990; 84:862.

199 Guariento A, Delascio D, De Macedo OB, Luisi A. Granuloma venéreo e gestaçao. Maternidade e Infáncia (Sao Paulo) 1965;21:124-47.

200 Anandam K. Study of granuloma venereum. Indian Journal of Dermatology, Venereology and Leprology 1979;45:323-32.

201 Wilson LA. Pregnancy and labor complicated by granuloma inguinale. JAMA 1930;95:1093-4.

202 Forti G, Benincori C. Doxycycline and the teeth. Lancet 1969;1:782.

203 Schultz JC, Adamson JS, Workman WW, Norman TD. Fatal liver disease after intravenous administration of tetracycline in high dosage. N Engl J Med 1963;269:999-1004.

204 Cherny WBV, Jones CP, Peete CH, Durham NC. Disseminated granuloma inguinale and its relationship to granuloma of the cervix and pregnancy. Am J Obstet Gynecol 1957;74:597-605.

205 Pund ER, McInnes GF. Granuloma venereum: a cause of death. Report of six fatal cases. Clinics 1944;3:221-34.

206 Guerriero WF, Jennett R, Mantooth WB. Infectious granulomatous lesions of the cervix. JAMA 1942;133:832-5.

207 Scott CW, Harper DM, Jason RS, Helwig EB. Neonatal granuloma venereum. Am J Dis Child 1952;85:308-15.

208 Parkash S, Radhakrishna K. Problematic ulcerative lesions in sexually transmitted diseases: surgical management. Sex Transm Dis 1986;13:127-33.

209 Giglioli G. Granuloma venereum-its diagnosis and treatment. Notes on fifteen cases treated with "Stibenyl" Heyden in British Guiana. J Trop Med Hyg 1928;31:245-54.

210 Nair VG, Pandalai NG. Granuloma genito-inguinale. Indian Medical Gazette 1934;69:361-72.

211 Scrimgeour EM, Sengupta SK, McGoldrick IA. Primary endometrial and endocervical granuloma inguinale (donovanosis). Br J Venereal Dis 1983;59:198-201.

212 Arnell RE, Potekin JS. Granuloma inguinale (granuloma venereum) of the cervix. An analysis of thirty-eight cases. $\mathrm{Am}$ J Obstet Gynecol 1940;39:626-35.

213 Hoosen AA, Draper G, Moodley J, Cooper K. Granuloma inguinale of the cervix: a carcinoma look-alike. Genitourin Med 1990;66:380-2.

214 Marmell M, Fielding WL, Weintraub S. Donovanosis of tubes and ovary treated with aureomycin and surgery. Am J Obstet Gynecol 1952;63:893-6.

215 Pund ER, Auerbach SH. Granuloma venereum (inguinale) of uterus, tubes and ovaries. Urologic and Cutaneous Review 1944;48:562-4.

216 Sengupta SK, Das N. Donovanosis affecting cervix, uterus, and adnexae. Am J Trop Med Hyg 1984;33:632-6.

217 Rajam RV, Rangiah PN, Anguli VC. Systemic donovaniasis. Br J of Venereal Dis 1954;30:73-80.

218 Lyford J, Johnson RW, Blackman S, Scott RB. Pathologic findings in a fatal case of disseminated granuloma inguinale with miliary bone and joint involvement. Bulletin of the Johns Hopkins Hospital 1946;79:349-57.

219 Jardim ML, Barros ER, Silveira M. Donovanose em pacientes portadores de AIDS. Relato de dois casos. Anais Brasileiros de Dermatologia e Sifilografia 1990;65:175-7.

220 O'Farrell N. AIDS, sex, and genital ulceration. Lancet 1988;1:355.

221 O'Farrell N, Windsor I, Becker P. Risk factors for HIV-1 amongst STD clinic attenders in Durban, South Africa. Poster presented at the 6th International Conference on AIDS, San Francisco, 20-24 June 1990 (abstract F.C. 604).

222 Ross TW, Kraupp RT. Granuloma inguinale. The beginning lesions contracted in the United States. Northwestern Medicine 1927;26:543-49.

Accepted for publication 2 September 199 